J. Clin. Chem. Clin. Biochem.

Vol. 17, 1979, pp. 219-223

\title{
Influence of Pyridoxal-5' -phosphate on the Determination of the Alanine Aminotransferase and Aspartate Aminotransferase of Commercial Test Sera
}

\author{
By J. C. M. Hafkenscheid and J. van der IVen-Jongekrijg \\ Laboratory for Clinical Chemistry, Department of Internal Medicine, St. Radboud Hospital, \\ University of Nijmegen, The Netherlands
}

(Received July 10/October 16, 1978)

\begin{abstract}
Summary: The influence of pyridoxal-5'-phosphate on the activities of alanine aminotransferase and aspartate aminotransferase from commercial test sera was investigated. Enhancement of the activity of alanine aminotransferase by the coenzyme is about $20 \%$ when $0.1 \mathrm{mmol} / 1$ of pyridoxal- 5 -phosphate is added to the reaction medium. This concentration seems sufficient for full saturation of the apoenzyme. For aspartate aminotransferase, the enhancement of the enzymatic activity is much higher than for alanine aminotransferase and $0.1 \mathrm{mmol} / \mathrm{l}$ of coenzyme is not sufficient for full saturation in this case.
\end{abstract}

In order to gain more insight into these differences in activity in commercial test sera, human sera were freeze dried and the aminotransferase activities determined after reconstitution. A decrease in activity of alanine aminotransferase was observed which could not be restored to the original level by the addition of pyridoxal-5'-phosphate. Thus it seems that freeze drying partially destroys alanine aminotransferase. After freeze drying the aspartate aminotransferase activity is also somewhat reduced, but the addition of pyridoxal- 5 -phosphate restores the activity completely. After freeze drying the degree of enhancement of the activity by the coenzyme is therefore higher than before freeze drying.

Comparing the results obtained from the commercial test sera and the freeze dried human sera it appears that the freeze drying process might be a reason for the low alanine aminotransferase activities mostly observed in test sera. The freeze drying process could also partly explain why the enhancement of the aspartate aminotransferase activity in commercial test sera by the coenzyme is higher than in normal human sera.

In general, it seems important that manufacturers of commercial test sera should supply values for aminotransferases which are determined in the absence and in the presence of pyridoxal-5'-phosphate.

\section{Einfluß von Pyridoxal-5' -phosphat auf die Bestimmung von Alaninaminotransferase und Aspartataminotransferase in kommerziellen Testseren}

Zusammenfasssung: Es wurde der Einfluß von Pyridoxal-5'-phosphat auf die Aktivität von Alaninaminotransferase und Asp̣artataminotransferase in kommerziellen Testseren untersucht. Die Zunahme der Aktivität beträgt, wenn $0,1 \mathrm{mmol} / 1$ Pyridoxal-5' ; phosphat dem Reaktionsgemisch zugefügt wird, etwa $20 \%$ für Alaninaminotransferase. Diese Konzentration ist ausreichend für vollständige Sättigung des Apoenzyms. Bei Aspartataminotransferase ist die Zunahme der Aktivität viel höher alš bei Alaninaminotransferase. Zusatz von $0,1 \mathrm{mmol} / 1$ Coenzym ist hier nicht genügend für vollständige Sättigung.

Um diese Unterschiede in der Aktivität von Aminotransferase in kommerziellen Testseren zu erklären, wurden Humanseren lyophilisiert und die Amịnotranșferase-Aktivitäten nach Rekonstitution bestimmt. Es wurde eine Abnahme der Alaninaminotransferase-Aktivität gefunden, die durch Zusatz von Pyridoxal-5' -phosphat nicht mehr zur ursprünglicher Aktivität zurückgeführt werden konnte. Die Alaninaminotransferase-Aktivität wurde beim Gefriertrocknen zum Teil zerstört. Nach Gefriertrocknen ist die Aspartataminotransferase-Aktivität ein wenig niedriger als vorher. Durch Zusatz von Pyridoxal-5' -phosphat konnte die Aktivität vollständig auf den ursprünglichen Wert zurückgeführt werden. Die Stimulierung der Aktivität durch das Coenzym ist also nach Gefriertrocknen höher als vorher. 
Aus den Ergebnissen, erhalten aus den kommerziellen Seren und den gefriergetrockneten Seren, schließen wir, daß das Gefriertrocknen eine Ursache der niedrigen Alaninaminotransferase-Aktivität sein kann, die oft in diesen Testseren beobachtet wird. Das Gefriertrocknen kann zum Teil erklären, daß die Stimulierung der Aspartataminotransferase durch das Coenzym in Testseren größer ist als in normalen Humanseren.

Es ist wichtig, daß die Hersteller der Testseren Werte für die Aminotransferase-Aktivitäten mitteilen, die mit und ohne Pyridoxal-5'-phosphat bestimmt sind.

\section{Introduction}

Over the past 10 years many papers have appeared concerning the determination of the two commonly measured serum aminotransferases. As a consequence American, British, German and Scandinavian recommendations for aminotransferase determinations have been published. The expert panel on enzymes of the Committee on Standards of the IFCC has also published an extensive provisional recommendation for the aspartate aminotransferase determination (1) ( $L$-aspartate: 2-oxoglutarate aminotransferase, EC 2.6.1.1). In this recommendation the addition of pyridoxal- $5^{\prime}$-phosphate to the reaction medium has been described. In the Scandinavian recommendation the addition of the coenzyme is discretionary (2).

Pyridoxal-5' -phosphate enhances serum aminotransferase activity by recombination with the apoenzyme. In general, an enhancement of $20-30 \%$ has been observed for normal and pathological sera. The concentration of the coenzyme employed in the various methods varies from 0.1 to $0.2 \mathrm{mmol} / 1(3-8)$. Usually a concentration of $0.1 \mathrm{mmol} / 1$ is used.

It is well known that most commercial test sera lack pyridoxal- $5^{\prime}$-phosphate. It is, therefore, understandable that the enhancing effect of the coenzyme on these control sera can be quite different from that of normal human sera. Jung et al. (9) observed a stimulation of $100 \%$ for aspartate aminotransferase activity in some control test sera using $0.2 \mathrm{mmol} / 1$ pyridoxal-5'. phosphate. Also the degree of enhancement of aspartate aminotransferase activity is higher than for the alanine aminotransferase ( $L$-alanine: 2 -oxoglutarate aminotransferase, EC 2.6.1.2).

Different causes can be suggested for these phenomena. The coenzyme may reassociate with the apoenzyme in human sera in a manner different from that in sera of animal origin. The difference in activation might depend on the source of enzymes which are added to the commercial test sera or on the method of freeze drying. Also the possibility cannot be excluded that additives like stabilizers can effect in some way the enzymatic activity.

In order to gain insight into these problems we have investigated the effect of pyridoxal- 5 -phosphate on various commercial test sera. We have also studied the influence of freeze drying on the activity of aspartate aminotransferase and alanine aminotransferase and the effect of pyridoxal-5'-phosphate on both aminotransferases from human sera.

\section{Materials and Methods}

The reconstitution of the freeze dried specimens was carried out as prescribed by the manufacturers.

Blood was taken by venepuncture. After centrifugation the serum samples were stored at $4{ }^{\circ} \mathrm{C}$ until the assay was carried out. Freeze drying of human sera was carried out in counting vials with $2 \mathrm{ml}$ of serum over a period of $24 \mathrm{~h}$ at $-50^{\circ} \mathrm{C}$ and at $0.3 \mathrm{kPa}$. After freeze drying $2 \mathrm{ml}$ of water was added to each of the counting vials. Before and after freezze drying, the sodium content of each of the samples was determined with a flame photometer (IL 343) to correct for volume differences.

Aminotransferase activities were determined at $37^{\circ} \mathrm{C}$ according to the recommendation of the Committee on Enzymes of the Scandinavian Society for Clinical Chemistry and Clinical Physiology (2). The final reaction mixture for the determination of the aminotransferases has been described previously (10). $0.5 \mathrm{ml}$ reaction medium was added to $0.075 \mathrm{ml}$ serum. After preincubation the reaction was started by the addition of $0.05 \mathrm{ml}$ 2-oxoglutarate.

All determinations were carried out at $37^{\circ} \mathrm{C}$ on the Automatic Kinetic Enzyme System (AKES, Vitatron, Dieren, The Netherlands) at $340 \mathrm{~nm}$ as described previously (10). Pyridoxal$5^{\prime}$-phosphate was dissolved in water and adjusted to the desired $\mathrm{pH}$ with $\mathrm{NaOH}$.

Reagent blank rate and sample blank rate were.determined under all experimental circumstances and the enzymatic activities were corrected for these blank rates.

All enzymatic determinations with the commercial test sera were carried out in 5 fold and the freeze drying experiments in triplicate.

All catalytic concentrations are expressed in $\mathrm{U} / \mathrm{l}$. The percentage increase in enzymatic activity after the addition of pyridoxal-5'phosphate was calculated by

$$
\frac{B-A}{A} \times 100 \%
$$

were

B is enzymatic activity in the presence of pyridoxal-5'-phosphate $A$ is enzymatic activity in the absence of pyridoxal-5'-phosphate

All chemicals were reagent grade and obtained from Boehringer; Mannheim.

Pyridoxal-5'-phosphate was purchased from Merck, Dạrmstadt.

\section{Results and Discussion}

Table 1 shows the aspartate aminotransferase activity of a number of freeze dried commercial test sera. The sera were of human, bovine and equine origin. Generally

\section{.}




\section{G]}

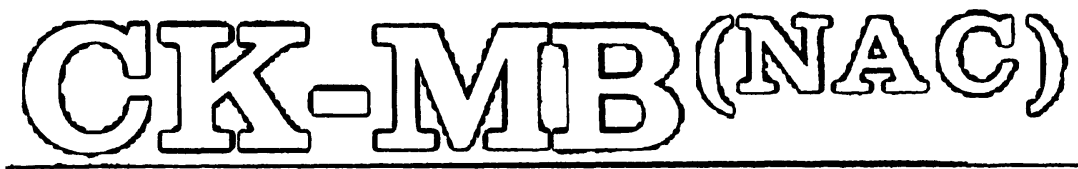

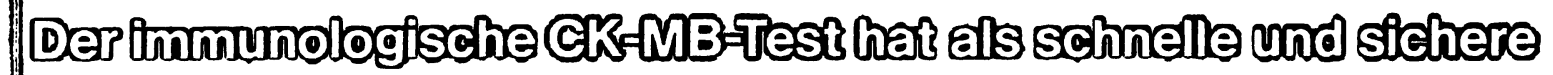

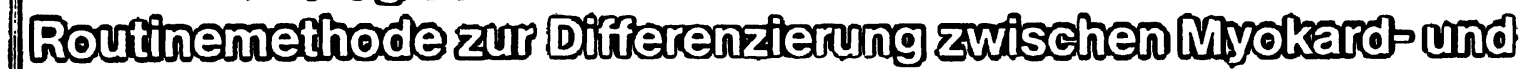

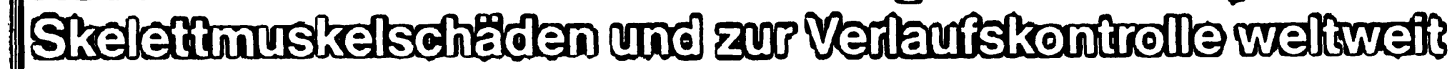
selne Bestatigung geftunden

Ftif das Vorllegen elines Myokardschadens spirechen:

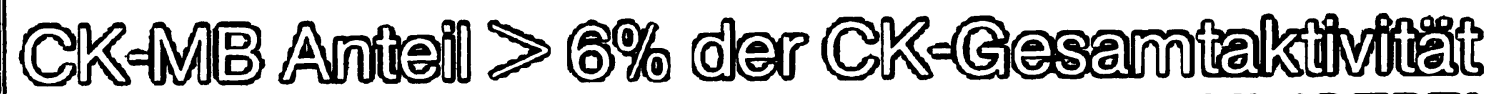

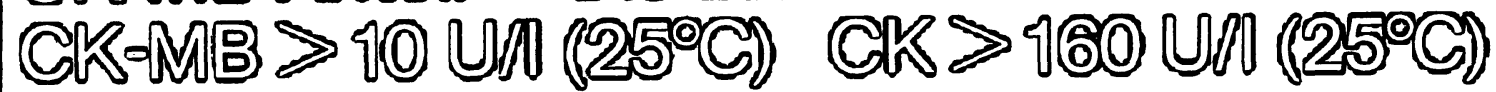

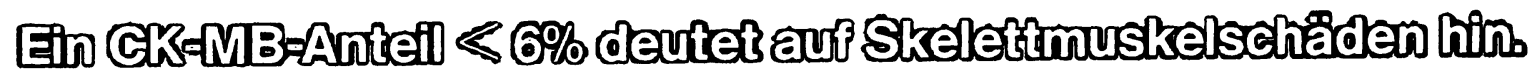
Ausnahomens

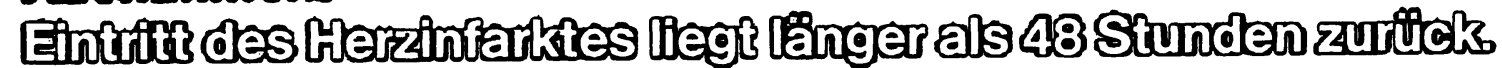

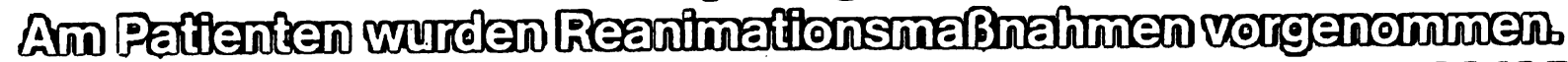

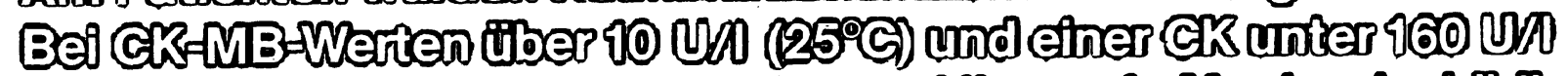

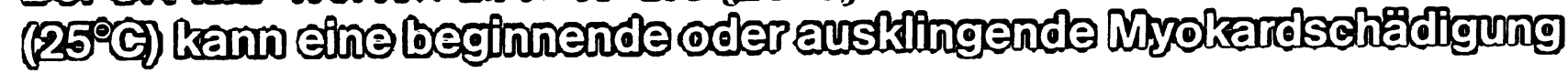
voriliegenb

In dilesem Graubereich empitehis sich eine erneute Probennahme

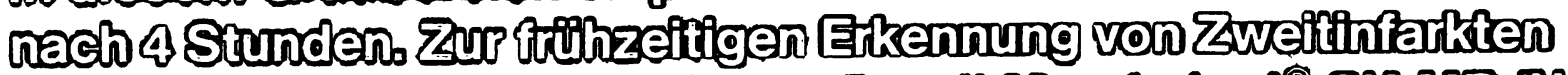

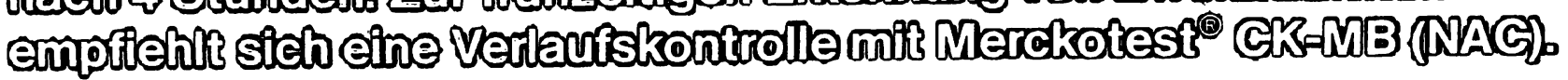

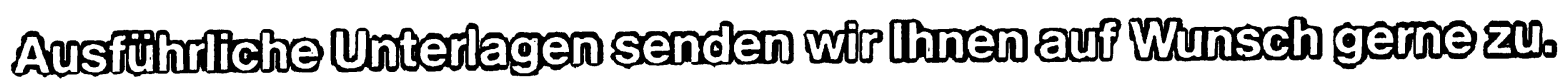




\section{0 mal...}

* mit jedem Knopfdruck dosieren Sie die genau gleiche Abgabeinenge 50mal mit einer Spritzenfuilling.

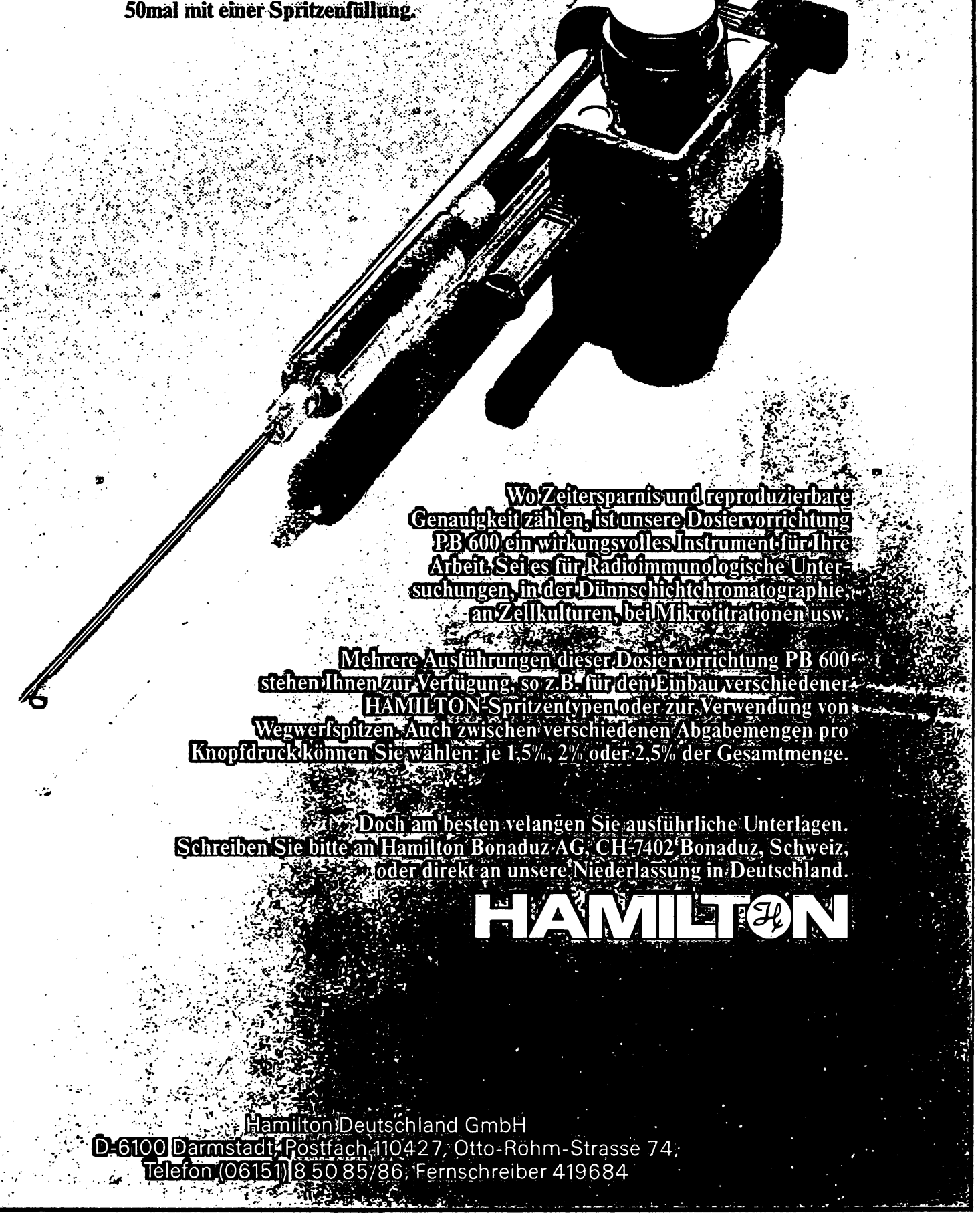


Tab. 1. Stimulation of activity of aspartate aminotransferase in freeze-dried test sera by pyridoxal- $5^{\prime}$-phosphate. Activities expressed in $U / L$

\begin{tabular}{|c|c|c|c|c|}
\hline $\begin{array}{l}\text { Concentra- } \\
\text { tion of } \\
\text { added } \\
\text { Pxl-P } \\
\text { (mmol/l) }\end{array}$ & 0.00 & 0.05 & 0.10 & 0.20 \\
\hline $\begin{array}{l}\text { Human } \\
\text { sera } \\
n=4\end{array}$ & 83.9 & $\begin{array}{l}114.3 \\
(36.2)\end{array}$ & $\begin{array}{c}131.3 \\
(56.5)\end{array}$ & $\begin{array}{c}140.3 \\
(67.2)\end{array}$ \\
\hline $\begin{array}{l}\text { Bovine } \\
\text { sera } \\
n=3\end{array}$ & 64.3 & $\begin{array}{r}94.1 \\
(46.3)\end{array}$ & $\begin{array}{c}109.7 \\
(70.6)\end{array}$ & $\begin{array}{c}115.2 \\
(79.2)\end{array}$ \\
\hline $\begin{array}{l}\text { Equine } \\
\text { sera } \\
n=12\end{array}$ & 88.2 & $\begin{array}{l}166.8 \\
(89.1)\end{array}$ & $\begin{array}{l}189.4 \\
(114.7)\end{array}$ & $\begin{array}{l}196.2 \\
(122.4)\end{array}$ \\
\hline
\end{tabular}

n: number of different test sera

Pxl-P: pyridoxal-5'-phosphate

In brackets percentage increase in activity

a high aspartate aminotransferase activity was present in the various samples. There is a very obvious enhancement of the enzymatic activity, when pyridoxal5 -phosphate is added to the reaction medium. It appears that the addition of the coenzyme in a concentration of $0.1 \mathrm{mmol} / 1$, which is most commonly used, is not enough for complete saturation of the apoenzyme under the test conditions.

In table 2 the activity of alanine aminotransferase of the same test sera is shown. The stimulation by the coenzyme is only about $20 \%$ and a concentration of $0.1 \mathrm{mmol} / 1$ seems enough for complete saturation of the apoenzyme.

Figure 1 shows the increase in activity of aspartate aminotransferase and alanine aminotransferase of all 19 test sera employed after the addition of pyridoxal5 -phosphate to the test medium.

Tab. 2. Stimulation of activity of alanine aminotransferase in freeze dried test sera by pyridoxal-5'-phosphate. Activities are expressed in $U / 1$.

\begin{tabular}{|c|c|c|c|c|}
\hline $\begin{array}{l}\text { Concentra- } \\
\text { tion of } \\
\text { added } \\
\text { Pxl-P } \\
\text { (mmol/1) }\end{array}$ & 0.00 & 0.05 & 0.10 & 0.20 \\
\hline $\begin{array}{l}\text { Human } \\
\text { sera } \\
n=4\end{array}$ & 52.4 & $\begin{array}{l}59.9 \\
(14.3)\end{array}$ & $\begin{array}{l}60.5 \\
(15.5)\end{array}$ & $\begin{array}{l}61.8 \\
(17.9)\end{array}$ \\
\hline $\begin{array}{l}\text { Bovine } \\
\text { sera } \\
n=3\end{array}$ & 65.2 & $\begin{array}{l}74.7 \\
(14.6)\end{array}$ & $\begin{array}{l}75.5 \\
(15.8)\end{array}$ & $\begin{array}{l}76.0 \\
(16.6)\end{array}$ \\
\hline $\begin{array}{l}\text { Equine } \\
\text { sera } \\
n=12\end{array}$ & 23.6 & $\begin{array}{l}28.5 \\
(20.8)\end{array}$ & $\begin{array}{l}28.7 \\
(21.6)\end{array}$ & $\begin{array}{l}28.2 \\
(19.5)\end{array}$ \\
\hline
\end{tabular}

n: number of different test sera

Pxl-P: pyridoxal-5'-phosphate

In brackets percentage increase in activity

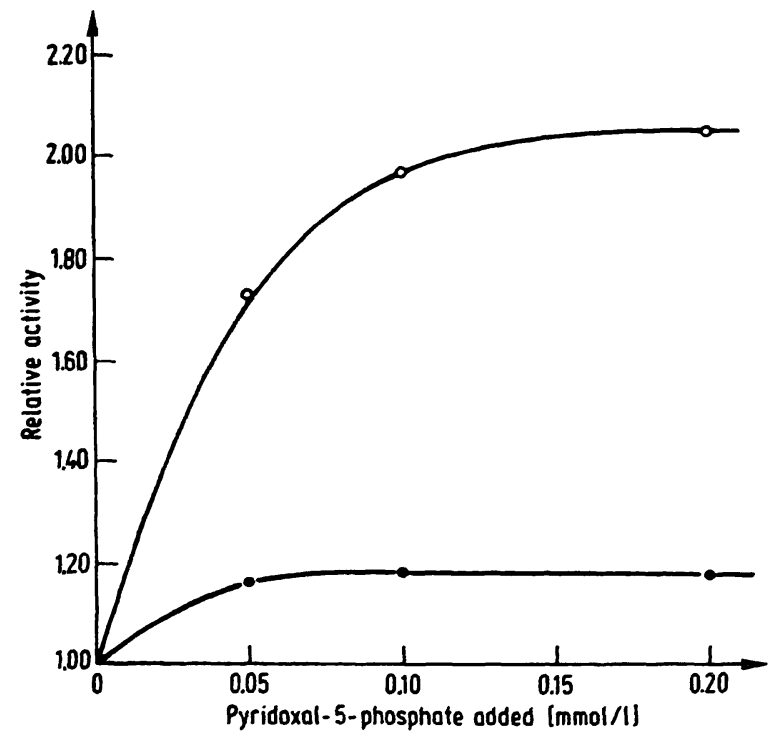

Fig. 1. Increase in enzymatic activity of aspartate aminotransferase and alanine aminotransferase from 19 different commercial test sera by addition of pyridoxal-5-phosphate.

- — alanine aminotransferase 0 _ $\circ$ aspartate aminotransferase

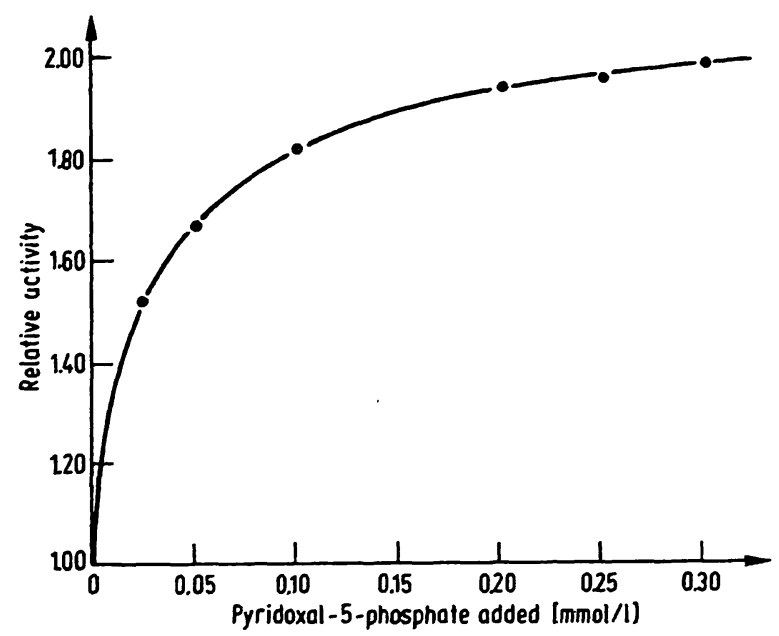

Fig. 2. Increase in enzymatic activity of aspartate aminotransferase from different commercial test sera by addition of pyridoxal-5'-phosphate.

It seems from this figure that even a concentration of $0.2 \mathrm{mmol} / \mathrm{l}$ of pyridoxal- 5 -phosphate is not enough to saturate the apoenzyme of aspartate aminotransferase. Therefore higher concentrations of the coenzyme were subsequently employed. It can be seen in figure 2 that a concentration of $0.2 \mathrm{mmol} / 1$ of the coenzyme is suboptimal for complete saturation of the aspartate aminotransferase apoenzyme of the 8 test sera investigated. A somewhat higher enhancement of the enzymatic activity was obtained with a concentration of $0.3 \mathrm{mmol} / 1$. Higher concentrations than $0.3 \mathrm{mmol} / 1$ cannot be recommended because of the high self absorbance of the coenzyme. 
To investigate the difference in enhancement of the activity by pyridoxal- 5 '-phosphate between commercial test sera and normal human sera, the effect of freeze drying on normal and pathological human sera was examined. Table 3 shows the influence of freeze drying on the alanine aminotransferase activity. After freeze drying, the enzymatic activity was decreased by about $15 \%$, while the enhancing effect of pyridoxal $-5^{\prime}$-phosphate was about the same, irrespective of whether or not the sera had been freeze dried.

The effect of freeze drying on the aspartate aminotransferase activity of human sera is shown in table 4. The enzymatic activity in the absence of pyridoxal-5'. phosphate is somewhat lower after freeze drying, but addition of the coenzyme to the reaction medium restores the activity to the original level. Thus the percentage increase in activity after freeze drying is higher than before.

The following general conclusions can be drawn:

\section{Commercial test sera}

1. The mean activation by pyridoxal- 5 '-phosphate is much greater for aspartate aminotransferase than for alanine aminotransferase.

2. The mean enzymatic activity of aspartate aminotransferase is much higher than that of alanine aminotransferase in the test sera investigated.
3. Addition of $0.1 \mathrm{mmol} / 1$ pyridoxal-5'-phosphate is not sufficient for maximal activation of aspartate aminotransferase.

4. Addition of $0.1 \mathrm{mmol} / \mathrm{l}$ pyridoxal. $5{ }^{\prime}$-phosphate is sufficient to saturate the alanine aminotransferase apoenzyme.

5. In general the 4 previous conclusions seem to be valid whether human, bovine or equine test sera were examined.

\section{Human sera}

1. A decrease in the enzymatic activity of alanine aminotransferase is observed after freeze drying. This might explain the low alanine aminotransferase activity in most commercial control sera.

2. Freeze drying of serum results in a decreased activity of alanine aminotransferase, measured in the presence of added pyridoxal-5'-phosphate.

It seems that the apoenzyme is partially destroyed by freeze drying, and that the addition of the coenzyme cannot restore this decrease in activity completely.

3. The percentage increase in alanine aminotransferase activity is quite the same before and after freeze drying. Bergmeyer et al (5) have observed that the alanine aminotransferase apoenzyme formed during

Tab. 3. Influence of freeze drying on the alanine aminotransferase activity of human sera. Activities expressed in $U / 1$.

\begin{tabular}{|c|c|c|c|c|c|c|}
\hline & \multicolumn{3}{|c|}{ Before freeze drying } & \multicolumn{3}{|c|}{ After freeze drying } \\
\hline & $-P x \mid-P$ & + Pxl-P & $\begin{array}{l}\text { Increase } \\
(\%)\end{array}$ & $-P \times 1-P$ & + Pxl-P & $\begin{array}{l}\text { Increase } \\
(\%)\end{array}$ \\
\hline $\begin{array}{l}\text { Normal sera } \\
n=64\end{array}$ & $\begin{array}{c}21.5 \\
(14-38)\end{array}$ & $\begin{array}{c}26.7 \\
(18-45)\end{array}$ & 24.2 & $\begin{array}{l}17.6 \\
(10-35)\end{array}$ & $\begin{array}{l}22.6 \\
(15-42)\end{array}$ & 28.4 \\
\hline $\begin{array}{l}\text { Pathological sera } \\
\mathrm{n}=19\end{array}$ & $\begin{array}{l}108.2 \\
(43-228)\end{array}$ & $\begin{array}{l}132.5 \\
(53-280)\end{array}$ & 22.5 & $\begin{array}{l}89.7 \\
(29-222)\end{array}$ & $\begin{array}{l}1.10 .5 \\
(39-267)\end{array}$ & 23.2 \\
\hline
\end{tabular}

$\mathrm{n}: \quad$ number of sera investigated

Pxl-P: pyridoxal-5'-phosphate $(0.1 \mathrm{mmol} / \mathrm{l})$

Range of observed activities is given between brackets

Tab. 4. Influence of freeze drying on the aspartate aminotransferase activity of human sera. Activities expressed in U/1.

\begin{tabular}{|c|c|c|c|c|c|c|}
\hline & \multicolumn{3}{|c|}{ Before freeze drying } & \multicolumn{3}{|c|}{ After freeze drying } \\
\hline & - PxI-P & $+P x \mid-P$ & $\begin{array}{l}\text { Increase } \\
(\%)\end{array}$ & $-P x \mid-P$ & + Pxl-P & $\begin{array}{l}\text { Increase } \\
(\%)\end{array}$ \\
\hline $\begin{array}{l}\text { Normal sera } \\
n=64\end{array}$ & $\begin{array}{l}24.4 \\
(18-37)\end{array}$ & $\begin{array}{c}31.7 \\
(23-45)\end{array}$ & 29.9 & $\begin{array}{l}22.7 \\
(18-37)\end{array}$ & $\begin{array}{c}32.8 \\
(26-46)\end{array}$ & 44.5 \\
\hline $\begin{array}{l}\text { Pathological sera } \\
n=19\end{array}$ & $\begin{array}{l}91.1 \\
(42-172)\end{array}$ & $\begin{array}{l}109.7 \\
(54-192)\end{array}$ & 20.4 & $\begin{array}{l}84.3 \\
(35-163)\end{array}$ & $\begin{array}{l}109,5 \\
(53-186)\end{array}$ & 29.9 \\
\hline
\end{tabular}

n: number of sera investigated

Pxl-P: pyridoxal-5'-phosphate

Range of observed activities is given between brackets. 
dialysis of a mixture of sera from patients is denatured and cannot be restored to its holoenzyme by adding pyridoxal phosphate. The average activation of 27 to $29 \%$ of the alanine aminotransferase activity remains unchanged (5). It seems that the results of Bergmeyer et al (5) are confirmed by our experiments, in which the sera have been freeze dried.

4. The aspartate aminotransferase activity is far less susceptible to the inactivation caused by the freeze drying process. Perhaps some endogenous coenzyme is released from the apoenzyme. Moreover, the addition of pyridoxal-5'-phosphate restores the activity completely. The aspartate apoaminotransferase therefore appears to remain fully intact during freeze drying. The freeze drying process can also partly explain why the enhancement of aspartate aminotransferase activity in commercial test sera is higher than in normal human sera.

In general it can be concluded that the determination of the aminotransferases in commercial test sera should be carried out in the presence of pyridoxal5 '-phosphate for the measurement of maximal activity. The freeze drying process, which is most usual in the preparation of commercial test sera, cannot fully explain why a high concentration of pyridoxal-5'-phosphate is necessary for a complete activation of the apoenzyme of aspartate aminotransferase. We agree with the conclusions of Burger \& Potgieter (11) that manufacturers of commercial test sera should supply values for aminotransferases, which are determined in the absence and in the presence of pyridoxal-5'-phosphate.

\section{Acknowledgement}

The authors wish to thank the Foundation for Quality Control of Clinical Chemical Hospital Laboratories in the Netherlands (Head Dr. A. P. Jansen) for making the commercial test sera available.

\section{References}

1. Provisional Recommendations on IFCC method for the measurement of catalytic concentrations of enzymes. Part 2 IFCC method for aspartate aminotransferase. (1976) Clin. Chim. Acta 70, F19. - F 42. - This J. 15, 39-51 (1977).

2. The Committee on Enzymes of the Scandinavian Society for Clinical Chemistry and Clinical Physiology. (1974) Scand. J. Clin. Lab. Invest. 33, 291-306.

3. Horder, M., Moore, R. E. \& Bowers Jr., G. N. (1976), Clin. Chem. 22, 1876-1883.

4. Rej, R. \& Vanderlinde, R. E. (1975), Clin. Chem. 21, 1585-1591.

5. Bergmeyer, H. U., Scheibe, P. \& Wahlefeld, A. W. (1978), Clin. Chem. 24, 58-73.
6. Moss, D. W. (1976), Clin. Chim. Acta 67, 169-174.

7. Jung, K. \& Egger, E. (1977), J. Clin. Chem. Clin. Biochem. $15,285-288$.

8. Jung, K., Lüdtke, B. \& Egger, E. (1975), J. Clin. Chem. Clin. Biochem. 13, 179-181.

9. Jung, K., Grützmann, K. D., Egger, E. \& Fechner, C. (1977), Clin. Chim. Acta 79, 515-526.

10. Hafkenscheid, J. C. M. \& Dijt, C. C. M. (1977), J. Clin. Chem. Clin. Biochem. 15, 519-521.

11. Burger, F. J. \& Potgieter, G. M. (1978), Clin. Chem. 24, 841.

Dr. J. C. M. Hafkenscheid Laboratory for Clinical Chemistry Department of Internal Medicine St. Radboud Hospital University of Nijmegen Nijmegen The Netherlands 
